\title{
High Growth and Diameter of the Stem of Corn Plants (Zea May, S) with a Different Cropping Pattern
}

\author{
Jamidi
}

Malikussaleh University, Aceh, Indonesia

\author{
Abdul Rauf, Chairani Hanum and Erwin Nyak Akop \\ North Sumatera University, Sumatera, Medan, Indonesia
}

\begin{abstract}
Purpose - The purpose of the research aims to observe the high growth of corn crops with a different cropping pattern.

Design/Methodology/Approach - The research is conducted based on field experiments with Group Randomized Design (hereafter RAK shortened from Cluster Random Design). The treatment of cropping pattern I is that corn crops are planted in one row with the size of plot $9 \mathrm{~m} \times 4 \mathrm{~m}$, and the distance planting of the crops is $70 \mathrm{~cm} \times 40 \mathrm{~cm}$. Cropping pattern II is that corn crops are planted in two rows with the size of plot $9 \mathrm{~m} \times 4 \mathrm{~m}$, and the distance planting is $70 \mathrm{~cm} \times 40 \mathrm{~cm}$. Cropping pattern III is that corn crops are planted in three rows with the size of plot $9 \mathrm{~m} \times 4 \mathrm{~m}$, and the distance among the crops is $70 \mathrm{~cm} \times 40 \mathrm{~cm}$.

Findings - The result of research shows that the highest corn crops are from cropping pattern II.3 at age 15 and 30 after planting time (called HariSetelahTanam or HST). The increase of cropping rows from one row to two rows indicates that intra-specific competition are more dominant. The growth of crops is faster because they need full sunlight at vegetative and generative stages. The need of full sunlight at the growing stage causes the increasing of stem height of crops to enable the crops to receive the sunlight optimally due to the continuity of photosynthesis process. The increasing growth of stem diameter is in accordance with the growth speed of height plant at the same age.
\end{abstract}

Research Limitations/Implications - This research intends to find out the best growing process of the plant. Further research is needed to study the outcome of final product of the plant.

Practical Implications - This is to see the utilization of the best cropping pattern and optimal land utilization.

Originality/Value - High growth of corn crops and stem diameter (Zea may, S) with a different cropping pattern has not yet been published.

Keywords Corn, crop height, stem diameter, population

All papers within this proceedings volume have been peer reviewed by the scientific committee of the Malikussaleh International Conference on Multidisciplinary Studies (MICoMS 2017).

(C) Jamidi, Abdul Rauf, Chairani Hanum, Erwin Nyak Akop. Published in the Emerald Reach Proceedings Series. Published by Emerald Publishing Limited. This article is published under the Creative Commons Attribution (CC BY 4.0) licence. Anyone may reproduce, distribute, translate and create derivative works of this article (for both commercial and non-commercial purposes), subject to full attribution to the original publication and authors. The full terms of this licence may be seen at http://creativecommons.org/licences/by/4.0/legalcode

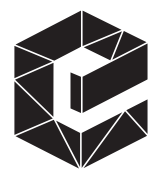




\section{Proceedings of 1 . Introduction}

MICoMS 2017 Photosynthesis needs full sunlight intensity. The sunlight absorption by plant headers is the prominent factor which determines the sustainable photosynthesis to yield photosync for the final formation result which are corn seeds. The sunlight is absorbed by plant headers proportionally with the total land shaded by plant headers (Rohtiq et al., 1999). The research development, to create superior height of plant, is conducted by arranging the distance of plants; thus, the population is diverse. The study indicates positive correlation between the height of corn stem and the great harvest. A research by Budiman et al. (2000: 320-337) mentions that 'hybrid' corn variety day 10, day 4, and day 1 (with height of $155.03 \mathrm{~cm}, 185.2$ $\mathrm{cm}$, and $192.74 \mathrm{~cm}$ ) produced more corn seeds compared to 'Arjuna' corn variety with the height of $174.62 \mathrm{~cm}$. Yet, the result is lower than "BISI 2"variety with height $184.18 \mathrm{~cm}$.

Light damping on a plant population based on law of Lambert Beer is $I=I o . e^{-k \mathrm{LLD}}$, in which $I=$ sunlight intensity on particular leaf layers; $I o=$ sunlight intensity on plant header; $e=$ natural Logarithm; $k=$ Coefficient of light damping; and ILD = wide index of cumulative leaf Gardner et al., 1991). The researches related with the light damping show that potential photosynthesis on one third of corn leaves at the top position is twice higher that the leaves at the middle position and five times higher than the leaves at the bottom position.

\section{Methods}

The research was conducted from April 2014 to April 2015 in barren land, Gampong Reuleut Barat Muara Batu Sub-District, Aceh Utara District, for which the topography and height of hill are $+7 \mathrm{~m}$ on sea level. The material used is a variety of Lamuru BS of corn composited from Balit Sereal Maros, manure from buffalo dung with doses of 15 tonnes/ha, and fertilizer of NPK gresik with doses of $200 \mathrm{~kg} / \mathrm{ha}$ as the basic fertilizer as well as pesticide of antracol 70 WP as support fertilizer to prevent from pest diseases. This research employs Group Randomized Design (RAK) Non-Factorial. The treatment of cropping pattern I is in one plot in which corn crops are planted in one row with a cropping distance of $70 \mathrm{~cm} \times 40 \mathrm{~cm}$; cropping pattern II is in one plot in which corn crops are planted in two rows with a cropping distance $70 \mathrm{~cm} \times 40 \mathrm{~cm}$; and cropping pattern III is in one plot in which corn crops are planted in three rows with a cropping distance $70 \mathrm{~cm} \times 40 \mathrm{~cm}$ with the plot size as $9 \mathrm{~m} \times 4 \mathrm{~m}$. Each cropping pattern has three arrangements of treatment combinations, so there are 27 plot units of experiment for one cropping pattern; the research results is tested further by using DMRT at a 5 percent level.

\section{Result and discussion}

\subsection{Corn plant height $(\mathrm{cm})$}

The average calculation of height of corn crops at the age of 15, 30, 45 and 60 days after planting time (called HST) based different cropping pattern, shows that the development tend to be linear. However on sample 10 and 14, it has exponential growth potency. Figures $1,2,3$ and 4 show the increasing height by the increasing of rows of corn crops from one row to three rows.It shows the interspecific competition more dominantly than intraspecific because the corn crops have stem growth higher than red chilli and soy plants. The increasing of stem height is also influenced by competition pattern on intercropping. Based on pictures 1 and 2 , it shows that the increasing of corn crop height is faster at the age of 15 and 30 after the planting time. The development of stem increases because the open leaves at that age are perfect. The plants enter to generative stage which is signed by the appearance of the prospective male flowers and the development of corncob.

Figure 3 and 4 do not show the increase of height growth stems because the plant has started entering generative phase. Most of photosync results starts to be dis-trans located to 


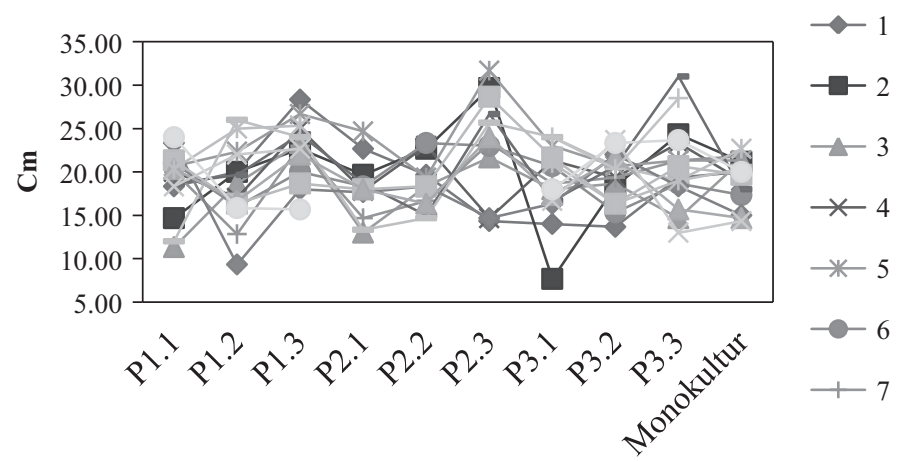

High Growth and Diameter

Treatment

\begin{tabular}{|c|c|c|c|c|c|}
\hline 1 & $\begin{array}{l}y=-0.571 x+22.17 \\
R^{2}=0.150\end{array}$ & 6 & $\begin{array}{l}y=-0.187 x+20.4 \\
R^{2}=0.043\end{array}$ & 11 & $\begin{array}{l}y=0.151 x+19.13 \\
R^{2}=0.016\end{array}$ \\
\hline 2 & $\begin{array}{l}y=0.231 x+18.81 \\
R^{2}=0.014\end{array}$ & 7 & $\begin{array}{l}y=0.462 x+16.62 \\
R^{2}=0.158\end{array}$ & 12 & $\begin{array}{l}y=-0.327 x+20.46 \\
R^{2}=0.100\end{array}$ \\
\hline 3 & $\begin{array}{l}y=0.345 x+16 \\
R^{2}=0.073\end{array}$ & 8 & $\begin{array}{l}y=-0.629 x+22.26 \\
R^{2}=0.293\end{array}$ & 13 & $\begin{array}{l}y=-0.629 x+22.26 \\
R^{2}=0.293\end{array}$ \\
\hline 4 & $\begin{array}{l}y=0.055 x+19.74 \\
R^{2}=0.002\end{array}$ & 9 & $\begin{array}{l}y=0.317 x+18.22 \\
R^{2}=0.034\end{array}$ & 14 & $\begin{array}{l}y=-0.422 x+23.79 \\
R^{2}=0.226\end{array}$ \\
\hline 5 & $\begin{array}{l}y=-0.143 x+23.95 \\
R^{2}=0.014\end{array}$ & 10 & $\begin{array}{l}y=16.13 e^{0,007 x} \\
R^{2}=0.008\end{array}$ & $\begin{array}{l}15 \\
16\end{array}$ & $\begin{array}{l}y=0.320 x+18.23 \\
R^{2}=0.101 \\
y=2.25 x+6.277 \\
R^{2}=0.302\end{array}$ \\
\hline
\end{tabular}
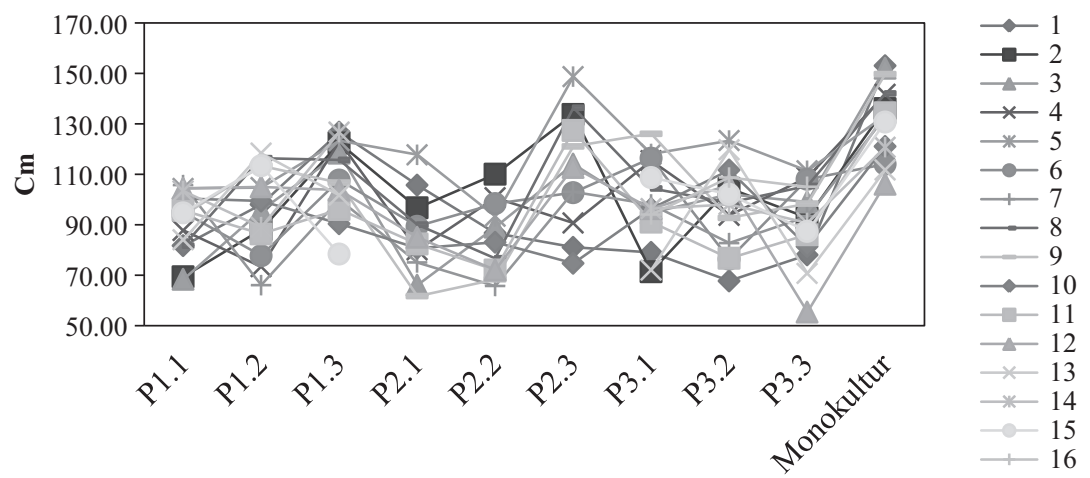

Treatment

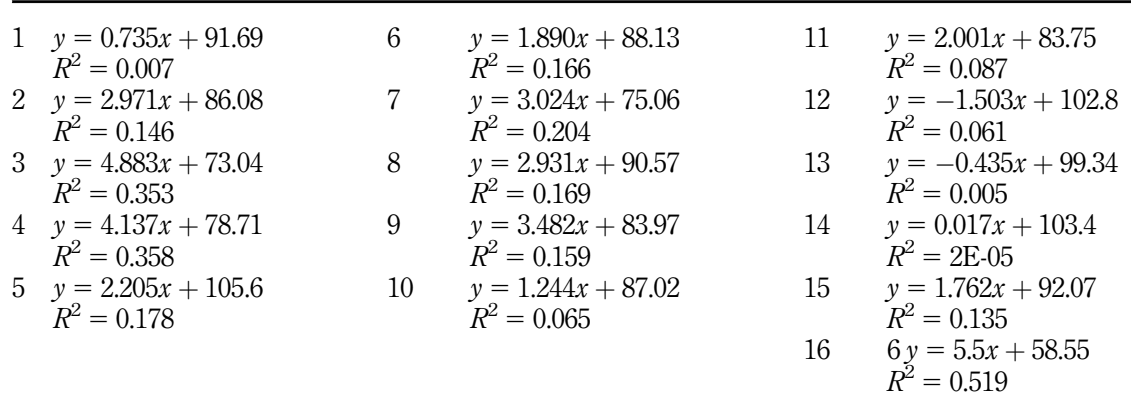

Figure 2.

The average height of corn plants at the age 30 days on different pattern 
Proceedings of MICoMS 2017

\section{2}

Figure 3.

The average height of 5 corn plants at the age 45days HST on different pattern

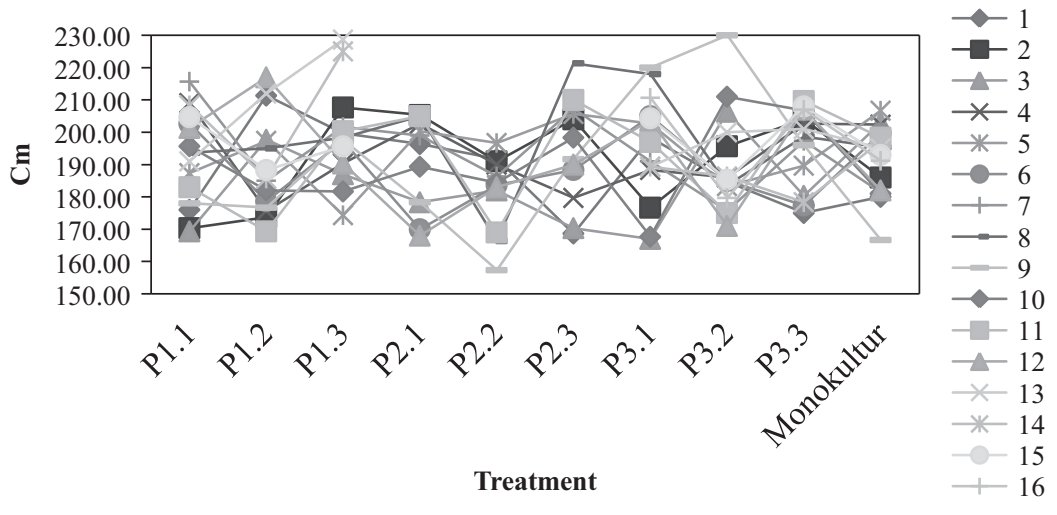

\begin{tabular}{|c|c|c|c|c|c|}
\hline 1 & $\begin{array}{l}y=-1.880 x+198.5 \\
R^{2}=0.178\end{array}$ & 7 & $\begin{array}{l}y=-2.155 x+205.8 \\
R^{2}=0.276\end{array}$ & 13 & $\begin{array}{l}y=-1.407 x+210.4 \\
R^{2}=0.137\end{array}$ \\
\hline 2 & $\begin{array}{l}y=1.335 x+184.0 \\
R^{2}=0.081\end{array}$ & 8 & $\begin{array}{l}y=0.371 x+195.4 \\
R^{2}=0.005\end{array}$ & 14 & $\begin{array}{l}y=-2.284 x+208.8 \\
R^{2}=0.267\end{array}$ \\
\hline 3 & $\begin{array}{l}y=1.410 x+176.3 \\
R^{2}=0.091\end{array}$ & 9 & $\begin{array}{l}y=2.147 x+177.4 \\
R^{2}=0.081\end{array}$ & & \\
\hline 4 & $\begin{array}{l}y=0.327 x+190.8 \\
R^{2}=0.008\end{array}$ & 10 & $\begin{array}{l}y=0.826 x+185.2 \\
R^{2}=0.036\end{array}$ & & \\
\hline 5 & $\begin{array}{l}y=1.099 x+188.3 \\
R^{2}=0.100\end{array}$ & 11 & $\begin{array}{l}y=1.882 x+181.3 \\
R^{2}=0.124\end{array}$ & & \\
\hline 6 & $\begin{array}{l}y=-1.373 x+198.8 \\
R^{2}=0.068\end{array}$ & 12 & $\begin{array}{l}y=-1.373 x+198.8 \\
R^{2}=0.068\end{array}$ & & \\
\hline
\end{tabular}

Figure 4.

The average height of 5 corn plants at the age 60days HST on different pattern
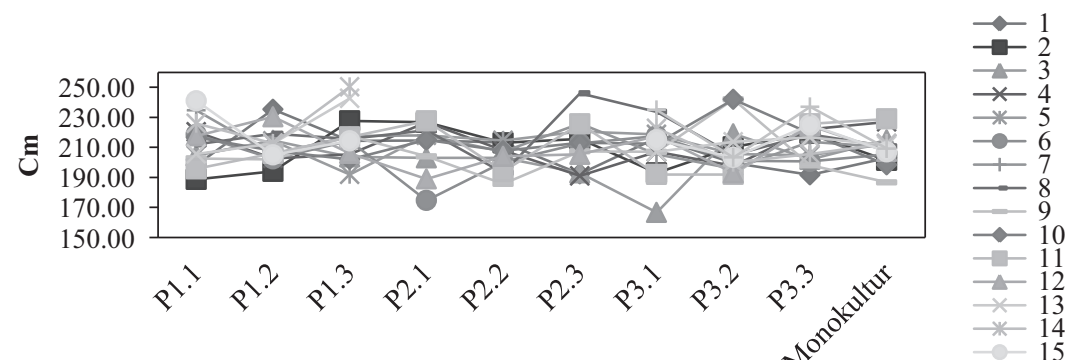

\section{Treatment}

\begin{tabular}{|c|c|c|c|c|c|}
\hline 1 & $\begin{array}{l}y=-2.121 x+219.5 \\
R^{2}=0.226\end{array}$ & 7 & $\begin{array}{l}y=-1.773 x+223.0 \\
R^{2}=0.226\end{array}$ & 13 & $\begin{array}{l}y=-0.579 x+218.9 \\
R^{2}=0.028\end{array}$ \\
\hline 2 & $\begin{array}{l}y=0.644 x+205.4 \\
R^{2}=0.019\end{array}$ & 8 & $\begin{array}{l}y=0.135 x+216.7 \\
R^{2}=0.000\end{array}$ & 14 & $\begin{array}{l}y=-2.570 x+233.2 \\
R^{2}=0.315\end{array}$ \\
\hline 3 & $\begin{array}{l}y=-0.230 x+203.7 \\
R^{2}=0.002\end{array}$ & 9 & $\begin{array}{l}y=-0.119 x+205.9 \\
R^{2}=0.000\end{array}$ & 15 & $\begin{array}{l}y=-1.406 x+223.8 \\
R^{2}=0.146\end{array}$ \\
\hline 4 & $\begin{array}{l}y=0.490 x+208.0 \\
R^{2}=0.014\end{array}$ & 10 & $\begin{array}{l}y=0.690 x+209.6 \\
R^{2}=0.030\end{array}$ & 16 & $\begin{array}{l}y=-4.393 x+258.4 \\
R^{2}=0.106\end{array}$ \\
\hline 5 & $\begin{array}{l}y=0.470 x+207.9 \\
R^{2}=0.026\end{array}$ & 11 & $\begin{array}{l}y=1.438 x+202.5 \\
R^{2}=0.073\end{array}$ & & \\
\hline 6 & $\begin{array}{l}y=-0.345 x+206.6 \\
R^{2}=0.006\end{array}$ & 12 & $\begin{array}{l}y=-0.682 x+213.2 \\
R^{2}=0.024\end{array}$ & & \\
\hline
\end{tabular}


enhance the size of the cob. The bigger cop the more seed will be produced. It is the nature of superior varietal which has high productivity potency.

The average growth of corn stem for lamuru varietal based on this research is lower than varietalas stated by Ciptaningtyas et al (2012).The research on dry land has the low soil fertility level which cause the height growth of the stem is lower than genetic potency. Abdurrahman et al. (2008) state that beside low fertility, the water limitation is also an issue of the dry land. The lack of water at root area and the excessive water demand by leaves because of the increasing of the evapotranspiration speed which exceeds the water absorption rate causes depressed growth of corn crop (Mathius et al. 2001). Water absorption can be maintained with the increase of density, and the plant can access the water soil easily with larger volume (Kamoshita et al., 2000).

\subsection{The diameter of the Base of the Stem}

The Figures 5, 6, 7 and 8 indicate the increasing of diameter of the base of the stem by the increasing of rows of the corn crops from one row to three rows. Thus, it shows the development of stem base is influenced by the competition among the crops because of the stem bases of corn crops have bigger diameter based on the first planting pattern.

The increasing of diameter of the base is faster at the age of 15 days and 30 days because the growth point has been located on the surface, the development and the spread of root is very fast, and the elongation of base occurs very fast which is followed by the development of diameter of the base. According to Figures 5 and 6, it revealed the development of different diameter of the base of the corn crop. The different respond of the crop is caused by the number of rows of plant in every different planting pattern. The inclining of the same population at particular planting pattern can cause the need of water, nutrient and sunlight in the same amount and at the same time.

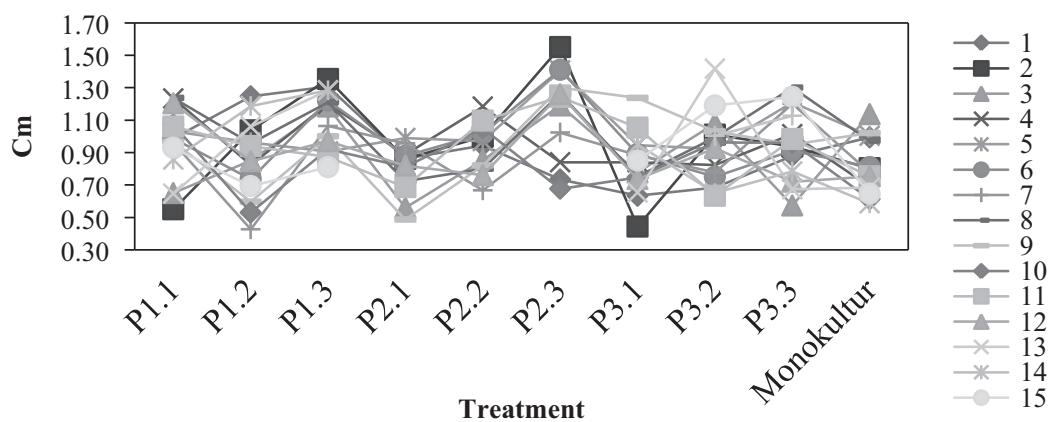

\begin{tabular}{|c|c|c|c|c|c|}
\hline 1 & $\begin{array}{l}y=-0.039 x+1.144 \\
R^{2}=0.290\end{array}$ & 6 & $\begin{array}{l}y=-0.013 x+1.037 \\
R^{2}=0.039\end{array}$ & 11 & $\begin{array}{l}y=0.017 x+0.788 \\
R^{2}=0.046\end{array}$ \\
\hline 2 & $\begin{array}{l}y=-0.005 x+0.981 \\
R^{2}=0.002\end{array}$ & 7 & $\begin{array}{l}y=0.014 x+0.791 \\
R^{2}=0.041\end{array}$ & 12 & $\begin{array}{l}y=-0.029 x+1.063 \\
R^{2}=0.216\end{array}$ \\
\hline 3 & $\begin{array}{l}y=0.017 x+0.788 \\
R^{2}=0.046\end{array}$ & 8 & $\begin{array}{l}y=-0.003 x+1.037 \\
R^{2}=0.001\end{array}$ & 13 & $\begin{array}{l}y=-0.015 x+1.006 \\
R^{2}=0.029\end{array}$ \\
\hline 4 & $\begin{array}{l}y=-0.035 x+1.150 \\
R^{2}=0.323\end{array}$ & 9 & $\begin{array}{l}y=0.035 x+0.746 \\
R^{2}=0.179\end{array}$ & 14 & $\begin{array}{l}y=-0.052 x+1.197 \\
R^{2}=0.527\end{array}$ \\
\hline 5 & $\begin{array}{l}y=0.011 x+0.972 \\
R^{2}=0.049\end{array}$ & 10 & $\begin{array}{l}y=-0.008 x+0.883 \\
R^{2}=0.020\end{array}$ & 15 & $\begin{array}{l}y=0.019 x+0.800 \\
R^{2}=0.089\end{array}$ \\
\hline
\end{tabular}

High Growth and Diameter

(1)


Proceedings of MICoMS 2017

\section{4}

Figure 6.

The average diameter of the base of the corn plants at the age of 30 days after planting timeof planting pattern one
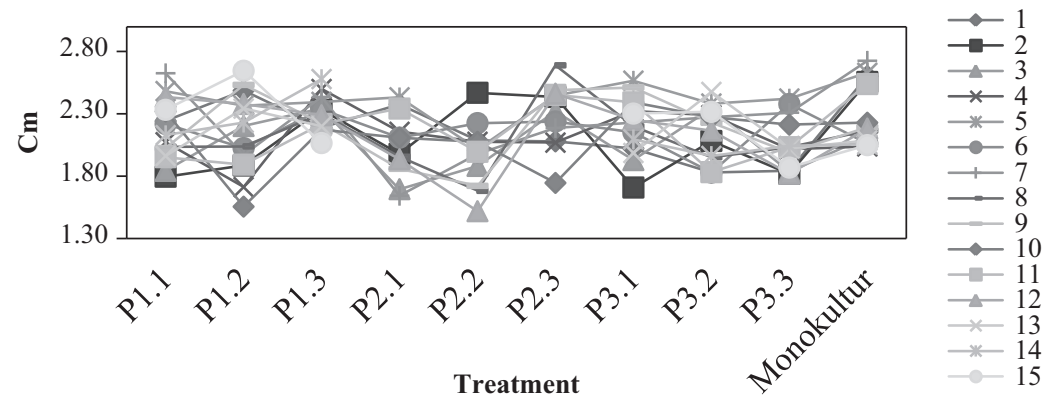

Treatment

$$
\begin{array}{ll}
6 & y=-0.008 x+2.202 \\
7 & R^{2}=0.022 \\
& y=0.026 x+2.090 \\
8 & R^{2}=0.063 \\
& y=0.006 x+2.068 \\
9 & R^{2}=0.006 \\
& y=0.002 x+2.164 \\
10 & R^{2}=0.000 \\
& y=0.029 x+1.949 \\
& R^{2}=0.113
\end{array}
$$

$$
\begin{array}{ll}
11 & y=0.029 x+2.001 \\
& R^{2}=0.126 \\
12 & y=-0.029 x+2.309 \\
& R^{2}=0.09 \\
13 & y=-0.001 x+2.163 \\
& R^{2}=0.000 \\
14 & y=-0.032 x+2.345 \\
& R^{2}=0.345
\end{array}
$$$$
y=0.015 x+2.332
$$$$
R^{2}=0.078
$$

\begin{tabular}{llllll}
\hline & & & \\
\end{tabular}




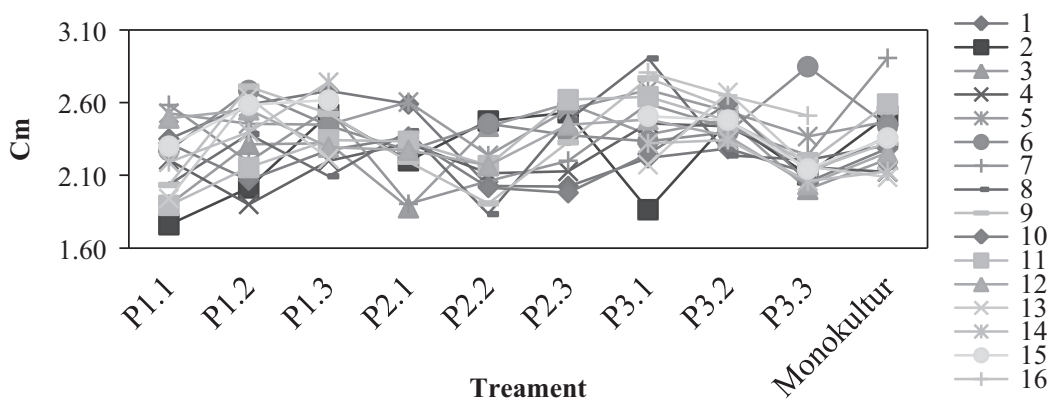

\begin{tabular}{llllll}
\hline 1 & $y=-0.038 x+2.532$ & 7 & $y=0.028 x+2.206$ & 13 & $y=2.247 e^{0.000 x}$ \\
& $R^{2}=0.236$ & & $R^{2}=0.084$ & & $R^{2}=0.000$ \\
2 & $y=0.037 x+2.038$ & 8 & $y=0.024 x+2.152$ & 14 & $y=-0.030 x+2.486$ \\
& $R^{2}=0.147$ & & $R^{2}=0.066$ & & $R^{2}=0.246$ \\
$3=0.019 x+2.146$ & 9 & $y=0.005 x+2.318$ & 15 & $y=-0.019 x+2.535$ \\
3 & $R^{2}=0.053$ & & $R^{2}=0.003$ & & $R^{2}=0.167$ \\
4 & $y=0.016 x+2.115$ & 10 & $y=0.004 x+2.193$ & 16 & $y=-0.148 x+3.842$ \\
& $R^{2}=0.086$ & & $R^{2}=0.005$ & & $R^{2}=0.998$ \\
5 & $y=-0.000 x+2.491$ & 11 & $y=0.051 x+2.055$ & & \\
& $R^{2}=0.000$ & & $R^{2}=0.410$ & \\
$y=0.015 x+2.364$ & 12 & $y=-0.026 x+2.484$ & & \\
6 & & & $R^{2}=0.252$ & & \\
& $R^{2}=0.068$ & &
\end{tabular}

High Growth and Diameter

105

Figure 8.

The average diameter of the base of corn plants at the age of 60 days (HST)

As the plant grows older at the day of 45 days after planting time, the increasing of diameter of the base of the stem becomes sluggish. At that age, the plant needs the nutrient in large amount for dis-translocation in order to be prospective male flower and the development of cob is about to start growing.

At the age of 60 days, biomasson the vegetative part is already maximal and the hair inside starts appearing. Furthermore, the plant performs pollination process and the prospective seeds start appearing. The vegetative development has stopped totally to complete the cop structure and the corn crop starts entering the physiological ripe phase.

Dry land is identical to water limitation and low soil fertility. The Lamuru type has a sturdy stem and genetically has a larger number of sclerenchyma tissue layers of stem compiler. The stem ability to store more water is better, which can fulfil the need of the water during the growing plant period. The good vegetative growth is an essential factor for this type to keep generative growth and productivity power although the land has limited water and low soil fertility.

\section{Conclusion}

The highest growth of stem corns is from cropping pattern III at the age of 15 and 30 HST. Intra-specific competition happens more dominantly in all cropping patterns; however, cropping pattern II with two rows can increase the growth or stem height faster because the cropping pattern enables the plants to obtain full sunlight at the vegetative stage due to the optimal space to grow. To increase the high growth of stem corns optimally, cropping pattern with two rows has to be applied. 


\section{Proceedings of References}

MICoMS 2017 Anonim. (2012). Available: http://pertanian.untag-smd.ac.id/../PerananAir_bagi_Pertumbuhan_Tanaman [accessed 24 November 2017].

Abdurachman, A., Dariah and Mulyani, A. (2008). "Strataegi dan teknologi pengelolaan lahan kering mendukung pengadaan pangan nasional”. Journal of Litbang Pertanian, Vol. 27, No. 2, pp. 43-49.

Budiman, L.F. and Sujiprihati, S. (2000). "Evaluasi Hasil dan Pendugaan Nilai Heterosis pada delapan Jagung Hibrida”. In Ekspose HasilPenelitian Bioteknologi Pertanian. Proceedings of Agriculture Department, Jakarta, pp. 320-337.

Ciptaningtyas, S.D., Indradewa, D. and Tohari. (2012). "Pengaruh interval penyiraman terhadap pertumbuhan dan hasil empat kultivar jagung (Zea mays L.)”. Vegetalika, Vol. 1, No. 4. Available: https://jurnal.ugm.ac.id/jbp/article/view/1592/1408 [accessed September 2017].

Fisher, K.S. and Palmer, A.F.E. (1996). "Jagung Tropik". In P.R. Goldsworthy and N.M. Fisher (Eds), Fisiologi Tanaman Budidaya Tropik, Translation. Tohari UGM Press, Yogyakarta, pp. 281-319.

Gardner, F. P, Peerce, R.B., Mithchel, R.L. (1985). "Physiology of Crop Plants". The Iowa State University Press.

Jones, M.M, Turner, N.C. and Osmond, C. B. (1981). "Mechanisms of Drought Resistance". In L.G. Paleg and D Aspinall (Eds), The Physiology and Biochemistry of Drought Resistance in Plants. Academic Press, Sydney, pp. 15-37.

Kamoshita, A., Wade, L.J. and Yamauchi, A. (2000). "Genotypic Variation in Response of Rainfed Lowland Rice to Drought and Rewatering. III. Water Extraction During the Drought Period. Plant Production Science, Vol. 3, pp. 189-196.

Mathius, N.T., Wijana, G. and Guharja, E. (2001). "Respons tanaman kelapa sawit (Elaeis guineensis Jacq.) terhadap cekaman kekeringan”. Menara Perkebunan, Vol. 69, No. 2, pp. 29-45.

Rohtiq, M., Sutzel, H. and Alt, C. (1999). "A Three-Dimensional Approach to Modelling Light Interception in Heterogeneous Canopies". Agronomy Journal, Vol. 91, pp. 1024-1103.

Salisbury, F.B. and Ross, C.W. (1995). Fisiologi Tumbuhan II (4th ed.). Translation D.R. Lukman and. Sumaryono. Bandung, ITB, p. 173.

Sitompul, S. M. and B. Guritno. (1995). “Analisis Pertumbuhan Tanaman”. UGM Press, Yogyakarta, p. 412 .

\section{Corresponding author}

Jamidi can be contacted at jamidi@unimal.ac.id 